\title{
PENGGUNAAN MEDIA POHON HURUF HIJA'IAH UNTUK MENINGKATKAN KEMAMPUAN MEMBACA
}

\author{
Kurnia Dewi \\ Program Studi Pendidikan Islam Anak Usia Dini - Fakultas Ilmu Tarbiyah dan Keguruan \\ Universitas Islam Negeri Raden Fatah
}

\begin{abstract}
Abstrak: Penelitian ini dilatarbelakangi oleh rendahnya kemampuan membaca huruf hija'iah pada anak Taman Kanak-kanak Tunas Harapan. Tujuan penelitian tindakan kelas ini adalah untuk meningkatkan kemampuan membaca huruf hija'iah pada anak kelompok Asoka melalui penggunaan media pohon huruf hija'iah. Subjek dalam penelitian ini yaitu kelompok Asoka Taman Kanak-Kanak Tunas Harapan Kota Bengkulu yang berjumlah 26 orang anak, yang terdiri dari 13 orang anak laki-laki dan 13 orang anak perempuan. Penelitian tindakan kelas ini dilakukan selama dua siklus, dimana siklus pertama 4 kali pertemuan dan siklus kedua 4 kali pertemuan. Pengumpulan data dalam penelitian ini dilakukan melalui observasi, dan dokumentasi dengan teknik analisis data secara deskriptif kualitatif sedangkan data penelitian ini diolah dengan persentase dan $t_{\text {test }}$. Hasil penelitian membuktikan bahwa penggunaan media pohon huruf hija'iah dapat meningkatkan kemampuan membaca, terbukti dengan hasil pengamatan yang dilakukan telah mencapai indikator keberhasilan 75\%. Dapat disimpulkan bahwa penggunaan media pohon huruf hija'iah dapat meningkatkan kemampuan membaca huruf hija'iah anak, hasil $t_{\text {test }}$ membuktikan bahwa $t_{\text {hitung }}$ sebesar 8,9 sementara $t_{\text {tabel }}$ 3,355 pada taraf signifikan 1\%, dengan demikian $t_{\text {hitung }}$ lebih besar dari $t_{\text {tabel }}$ sehingga perhitungan uji $t_{\text {test }}$ pada penilaian ini dikatakan signifikan. Dalam penggunaan media pohon huruf hija'iah untuk meningkatkan kemampuan membaca anak, direkomendasikan seorang guru harus menyiapkan hal-hal yang mendukung terlaksananya pembelajaran menggunakan media pohon huruf yang menarik sesuai dengan tahapan perkembangan dan kebutuhan anak.
\end{abstract}

Kata Kunci: Media Pohon Huruf Hija'iah, Kemampuan Membaca. 


\section{Pendahuluan}

Menurut Undang-undang Republik Indonesia nomor 20 tahun 2003 tentang sistem pendidikan nasional pasal 1 angka 14, menyatakan bahwa Pendidikan Anak Usia Dini adalah suatu upaya pembinaan yang ditunjukan kepada anak sejak lahir sampai dengan usia enam tahun yang dilakukan melalui pemberian rangsangan pendidikan untuk membantu pertumbuhan dan perkembangan jasmani dan rohani agar anak memiliki kesiapan dalam memasuki pendidikan lebih lanjut (Permendiknas no. 58, 2009: 1).

Undang-Undang nomor 20 tahun 2003 menegaskan bahwa Pendidikan Anak Usia Dini dapat diselenggarakan melalui jalur pendidikan formal, non formal dan informal. PAUD jalur formal berbentuk Taman Kanak-kanak, Raudhatul Athfal, atau bentuk lain yang sejenis. Sedangkan PAUD jalur non-formal berbentuk Kelopok Bermain. Sementara PAUD jalur informal berbentuk Tempat Penitipan Anak atau bentuk lain yang sederajat.
Pembelajaran huruf hija'iah adalah kegiatan pembelajaran tambahan wajib yang di selenggarakan di TK Tunas Harapan. Dimana pembelajaran huruf hija'iah ini tidak ada secara khusus atau mendetail di kurikulum 2010 dan permendiknas 58 yang merupakan acuan pengajaran. Hal ini dikarenakan penduduk Negara Indonesia tidak hanya memeluk agama Islam tetapi memeluk bermacam-macam agama.

Keterampilan membaca AlQur'an di awali dengan pengenalan huruf hija'iah. Salah satu metode yang menumbuhkan minat anak adalah menggunakan media pohon huruf hija'iah, karena dalam kegiatan belajar menggunakan media pohon huruf hija'iah proses pembelajaran berpusat pada anak dimana guru menjadi fasilitator dan motivator, anak diberi kesempatan untuk aktif dalam belajar.

Berdasarkan pengamatan penulis di TK tunas harapan kota Bengkulu, pada saat praktek mengajar, peneliti menemukan masih kurangnya atau rendahnya kemampuan guru dalam merangsang kemampuan membaca huruf hija'iah 
anak pada saat kegiatan pembelajaran, selain kemampuan guru yang terbatas, juga media yang digunakan dalam pembelajaran tidak menarik dan cendrung monoton.

Disini penulis mencoba meningkatkan kemampuan membaca huruf hija'iyah anak dengan menggunakan media yang mampu menarik perhatian anak yaitu dengan menggunakan media pohon huruf hija'iah.

Keterampilan membaca AlQur'an di awali dengan pengenalan huruf hija'iah. Salah satu metode yang menumbuhkan minat anak adalah menggunakan media pohon huruf hija'iah, karena dalam kegiatan belajar menggunakan media pohon huruf hija'iah proses pembelajaran berpusat pada anak dimana guru menjadi fasilitator dan motivator, anak diberi kesempatan untuk aktif dalam belajar.

Dalam Penelitian Tindakan Kelas (PTK) ini media yang digunakan dalam pembelajaran yaitu media pohon huruf hija'iah dimana melalui media pohon huruf hija'iah guru mampu melihat tingkat kemampuan membaca huruf hija'iah anak kelompok Asoka taman kanak- kanak tunas harapan kota bengkulu dan dapat memberikan sumbangan pemikiran dalam rangka pengembangan ilmu Pendidikan Anak Usia Dini terutama yang berhubungan dengan hal-hal yang mempengaruhi keberhasilan belajar anak tentang kemampuan membaca huruf hija'iah, serta dapat dijadikan sebagai sumbangan pemikiran untuk lebih meningkatkan kemampuan membaca huruf hija'iah pada anak dalam ragka pengembangan kualitas sumberdaya manusia yang berkualitas.

Huruf hija'iah adalah Intisari Asma-asma Allah Ta'ala. Terdiri آبت ث ج dari 28 huruf hija'iah yaitu ح خ د ذ ر ز س ش ص ض طظ ع غ ف ق ك ل ل م ن و ه Pohon huruf hija'iah adalah media yang dapat digunakan untuk kegiatan pembelajaran huruf hija'iah yang berbentuk pohon dan memiliki buah yang mana disetiap buahnya terdapat huruf-huruf hija'iah dari alif (آ) sampai ya (ي).

Berdasarkan latar belakang di atas, maka permasalahan peneliti adalah Apakah melalui media pohon huruf hija'iah dapat meningkatkan kemampuan membaca huruf hija'iah pada anak kelompok Asoka Taman 
Kanak-kanak Tunas Harapan Kota

Bengkulu?"

\section{Kajian Pustaka}

Menurut Dhieni dkk, (2007:5.5), mengemukakan bahwa membaca merupakan keterampilan bahasa tulis yang bersifat reseptif. Sedangkan Menurut Anderson dkk dalam Dhieni dkk, (2007:5.5), memandang membaca sebagai suatu proses untuk memahami makna suatu tulisan. Adapun Menurut Hari dalam Dhieni dkk, (2007:5.5), menyatakan membaca merupakan interprestasi yang bermakna dari simbol verbal yang tertulis atau tercetak. Kridalaksana dalam Dhieni dkk, (2007:5.5), juga mengemukakan bahwa membaca adalah keterampilan mengenal dan memahami tulisan dalam bentuk urutan lambanglambang grafis dan perubahannya menjadi wicara bermakna dalam bentuk pemahaman diam-diam atau pengujaran keras-keras.

Dari beberapa pendapat di atas dapat di simpulkan bahwa membaca adalah suatu kegiatan atau keterampilan dalam mengenal dan memahami simbol verbal suatu tulisan. Kegiatan tersebut berkaitan dengan pengenalan huruf, bunyi huruf, pemahaman tulisan dan mencari tau makna dari apa yang di baca.

Menurut Fahmi, Khotib, dan Baedhowi (1993:28), mengemukakan bahwa mengenal huruf hija'iah melalui kalimat atau kata. Huruf hija'iah berjumlah 28 namun menjadi 29 huruf dengan آ ب ت ث جح حخد ذذرز : س ش ص ض طظع غ ف ق ك ل م ن و هي

Adapun beberapa tanda baca huruf hija'iah, 1) Fathah adalah tanda baca berupa garis panjang diatas huruf hija'iah (-́). Huruf hija'iah bertanda baca fathah jika dibaca akan berbunyi hidup a, 2) Kasrah adalah tanda baea berupa garis miring dibawah huruf hija'iah (, ). Huruf hija'iah bertanda baca kasrah jika dibaca akan berbunyi i, 3) Dummah adalah tanda baca yang berbetuk koma diatas huruf hija'iah (, ). Huruf bertanda baca dummah jika dibaca akan berbunyi u, 4) fathah tanwin adalah tanda bacan yang berbentuk garis miring ganda sejajar diatas di atas huruf hija'iah ( - ). Apabila dibaca, akan berbunyi an. Kasrah tanwin adalah tanda baca yang berbentuk garis 
miring ganda sejajar dibawah huruf hija'iah ( -). Apa bila dibaca, akan berbunyi in.

Ada beberapa faktor yang perlu diperhatikan dalam membaca huruf hija'iah, karena huruf hija'iah adalah huruf awalan Al-Quran dan mengenal huruf hija'iah adalah sebagai dasar membaca Al-Quran.

Media pengajaran menurut Harjonto, 2010 dibagi dua bagian yaitu media dalam arti sempit dan media dalam arti luas. Dalam arti sempit, media pengajaran hanya meliputi media yang dapat digunakan secara efektif dalam proses pengajaran yang terencana, sedangkan dalam arti luas, media tidak hanya meliputi media komunikasi elektronikyang kompleks akan tetapi juga mencakup alat-alat sederhana seperti slide, fotogarfi, diagram dan bagan buatan guru seperti pohon huruf hija'iah.

Menurut Gagne dalam Dhieni dkk, (2007:10.3), media adalah berbagai jenis komponen dan lingkungan anak didik yang dapat memotivasi anak didik untuk belajar. Sedangkan menurut Briggs dalam Dhieni dkk, (2007:10.3), mengemukakan media adalah segala alat fisik yang dapat menyajikan pesan serta merangsang anak didik untuk belajar.

Sedikit berbeda dengan pendapat di atas, National Education Associatiom dalam Dhieni dkk, (2007:10.3), menyatakan media adalah bentukbentuk komunikasi baik tercetak maupun audio visual serta peralatannya. Media hendaknya dapat dimanipulasi, dapat dilihat, didengar dan dibaca. Selanjutnya menurut Association of Education Dan Communication Technolog dalam Dhieni dkk, (2007:10.3), Mereka mengemukakan bahwa media sebagai segala bentuk dan saluran yang digunakan orang untuk menyalurkan pesan/informasi. Menurut Hamalik dalam Dhieni dkk, (2007:10.3), pakar pendidikan Indonesia menyatakan media adalah alat, metode dan teknik yang digunakan dalam rangka lebih mengefektifkan komunikasi dan interes antara guru dan anak didik dalam proses pendidikan dan pembelajaran disekolah.

$$
\text { Dari batasan yang }
$$
disampaikan para ahli mengenai 
media, maka dapat disimpulkan bahwa pengertian media dalam pembelajaran adalah segala bentuk dan alat komunikasi yang dapat digunakan untuk menyampaikan pesan atau informasi dari sumber kepada anak didik yang bertujuan agar dapat merangsang pikiran, pesan, minat dan perhatian anak didik untuk mengikuti kegiatan pembelajaran. Dalam pembelajaran huruf hija'iah media merupakan sarana yang dapat digunakan untuk membantu guru dalam kegiatan pembelajaran guna mencapai tujuan pembelajaran.

Asnawir,

mengemukakan Media pengajara digunakan dalam rangka upaya peningkatan atau mempertinggi mutu proses kegiatan belajarmengajar. Oleh karena itu harus diperhatikan bebrapa prinsip-prinsip penggunaanya antara lain: (1) Penggunaan media pengajaran hendaknya dipandang sebagai bagian integral dari suatu sistem pengajaran dan bukan hanya sebagai alat bantu yang berfungsi sebagai tambahan yang digunakan bila dianggap perlu dan hanya dimanfaatkan sewaktu-waktu, (2)
Media pengajaran hendaknya dipandang sebagai sumber belajar yang digunakan dalam usaha memecahkan masalah yang dihadapi dalam proses belajar-mengajar karena dalam proses belajar guru benar-benar menguasai teknikteknik dari suatu media pengajaran yang digunakan. Namun juga seharus memperhitungkan untung ruginya pemanfaatan suatu media pengajaran, (3) Penggunaan media pengajaran harus diorganisir secara sistematis bukan sembarang mengunakannya, (4) Jika sekiranya suatu pokok bahasan memerlukan lebih dari satu macam media, maka guru dapat memanfaatkan multi media yang menguntungkan dan memperlancar proses belajarmengajar dan juga dapat merangsang anak aktif dalam belajar.

Manfaat positif dari penggunaan media sebagai bagian integral pengajaran di kelas menurut Hamalik, (2005:26), adalah sebagai berikut: Dapat menyampaikan pelajaran menjadi lebih baku dan lebih menarik. Setiap anak yang melihat atau mendengar penyajian melalui media menerima pesan yang 
sama dapat diasosiasikan sebagai penarik perhatian dan membuat anak tetap terjaga dan memperhatikan. Pembelajaran juga akan menjadi lebih interaktif dengan diterapkannya teori belajar dan prinsip-prinsip psikologis yang diterima dalam hal partisipasi anak, umpan balik, dan penguatan.

Pembelajaran dengan menggunakan mediapun akan mempersingkat waktu untuk mengantarkan pesan-pesan dan isi pelajaran namun tetap kualitas hasil belajar dapat ditingkatkan karena peran guru dapat berubah proses belajar kearah yang lebih positif.

Secara umum manfaat media pembelajaran adalah memperlancar interaksi antara guru dengan anak sehingga kegiatan pembelajaran lebih afektif dan efisien. Sedangkan secara lebih khusus manfaat media pembelajaran adalah: (1) Dalam penyampaian materi pembelajaran dapat diseragamkan. (2) Proses pembelajaran menjadi lebih jelas dan menarik, (3) Proses pembelajaran menjadi lebih interaktif karena dengan media akan terjadinya komukasi dua arah secara aktif, sedangkan tanpa media guru cenderung bicara satu arah, (3) Dengan media tujuan belajar akan lebih mudah tercapai secara maksimal dengan waktu dan tenaga seminimal mungkin,

Meningkatkan kualitas hasil belajar anak, (5) Media memungkinkan proses belajar dapat dilakukan di mana saja dan kapan saja, (6) Media dapat menumbuhkan sikap positif anak terhadap materi dan proses belajar, (7) Mengubah peran guru ke arah yang lebih positif dan produktif

Menurut Dhieni dkk, (2007:11.3), media pembelajaran memiliki beberapa jenis, yaitu: 1 Media Audio atau biasa disebut dengan media dengar yang dapat menyampaikan pesan melalui suara dan bunyi seperti suara bahasa, musik, dan sound effect dapat dikombinasikan untuk menguatkan isi pesan. Sedangkan menurut Anderson dalam Dieni dkk, (2007:11.3), menyatakan media audio merupakan bahan ajaran yang ekonomis, menyenangkan dan mudah disiapkan untuk digunakan oleh anak. Media audio dibagi menjadi dua yaitu, media Rekaman/Tape Recorder dan media 
radio. 2 Media visual yaitu media yang dapat digunakan untuk menyampaikan pesan/informasi melalui penglihatan yang berbentuk simbol-simbol visual. Macammacam media visual yaitu, (1) media garis/bahan cetakan/ suplementary materials, (2) gambar, (3) sketsa, (4) poster, (5) kartun, (6) peta dan gelobe, (7) papan planel/planel board, (8) papan buletin/ bulletin board. 3 Media audio visual adalah media yang dapat menyampaikan pesan melalui suara, gambar, dan tulisan. Media audio visual di bagi menjadi dua macam, yaitu media televisi dan film.

Telah dijelaskan di atas bahwa jenis media pembelajaran terbagi menjadi tiga yaitu media audio, media visual dan media audio visual. Dalam penelitian ini, media yang digunakan peneliti termasuk kedalam media visual yaitu jenis media Pohon huruf hija'iah. Media ini berbentuk pohon dan memiliki buah yang mana disetiap buahnya terdapat hurufhuruf hija'iah dari alif (أ) sampai ya (ي) sehingga pembelajaran lebih menyenangkan karena memiliki tampilan yang menarik dan cocok digunakan untuk Anak Usia Taman Kanak-kanak.

\section{Metode Penelitian}

Jenis penelitian yang digunakan pada penelitian ini adalah jenis penelitian Penelitian Tindakan Kelas. Penelitian Tindakan Kelas merupakan suatu pencermatan terhadap kegiatan belajar berupa sebuah tindakan, yang sengaja dimunculkan dan terjadi dalam sebuah kelas secara bersama (Arikonto, 2011;3)

Adapun sobjek dalam penelitan ini adalah Taman Kanakkanak Tunas Harapan Jl. Dempo Sawah Lebar Kota Bengkulu dan terfokus pada anak kelompok Asoka yang berjumlah 26 orang yang terdiri dari 13 orang anak laki-laki dan 13 orang anak perempuan

Data yang dikumpulkan adalah data yang bersifat kualitatif. Teknik pengumpulan data pada penelitian ini dilakukan dengan menggunakan Teknik pengumpulan data yang di gunakan adalah observasi dan dokumentasi.

Sutrisno Hadi dalam Sugiono, (2011: 166), mengemukakan bahwa, observasi merupakan suatu proses 
yang kompleks, suatu proses yang tersusun dari berbagai proses biologis dan psikologis. Dua di antara yang terpenting adalah prosesproses pengamatan dan ingatan. Peneliti memilih untuk menggunakan teknik ini karena melalui teknik ini akan lebih memudahkan peneliti dalam mengamati anak secara langsung dan sekaligus dapat memberikan bantuan kepada anak yang belum mampu membaca sesuai urutan huruf hija'iah, membaca huruf hija'iah sesuai tanda baca fathah dan kasrah dengan baik dan benar. Halhal yang dievaluasi adalah kemampuan membaca huruf hija'iah yaitu membaca sesuai urutan huruf hija'iah, membaca huruf hija'iah sesuai tanda baca fathah dan kasrah.

\section{Hasil Penelitian dan Pembahasan}

Data hasil sikulus pertama pertemuan pertama pada tiga kegiatan pembelajaran yang telah dilakukan peneliti dan teman sejawat memperoleh data rata-rata tidak baik, kemudian peneliti melakukan refleksi huruf yang susah di ingat anak, maka pada pertemuan berikutnya guru/peneliti harus lebih menekankan pembelajaran pada huruf yang susah di ingat anak hingga pertemuan keempat siklus pertama memperoleh nilai rata-rata cukup.

Berdasarkan data diatas dapat diketahui bahwa pada siklus pertama yang dilakukan dengan tema tanaman dan sub tema jenis-jenis tanaman dan dilakukan sebanyak empat kali pertemuan dengan aspek yang diamati adalah kemampuan membaca huruf hija'iah secara urut, sesuai tanda baca fathah dan kasrah. Kemampuan anak selalu mengalami peningkatan tiap kali pertemuan, sudah ada anak mendapatkan kriteria cukup tapi masih ada beberapa anak yang mendapatkan nilai kurang.

Dari hasil analisis pada siklus pertama, dalam penelitian ini masih banyak terdapat kekurangan dan masih ada kemampuan anak yang belum mencapai standar indikator keberhasilan, sehingga peneliti perlu mengadakan perbaikan untuk meningkatkan kemampuan membaca huruf hija'iah anak yang belum mencapai indikator keberhasilan, oleh karena itu peneliti melanjutkan penelitian ini pada siklus kedua agar tujuan meningkatkan kemampuan anak dalam membaca huruf hija'iah 
secara urut, sesuai tanda baca kasrah dan fathah mampu mencapai standar indicator Berdasarkan data di atas dapat diketahui bahwa kemampuan anak membaca huruf hija'iah secara urut, sesuai tanda baca fathah dan kasrah pada siklus pertama yang dilakukan sebanyak empat kali pertemuan belum memenuhi target indikator keberhasilan minimal yaitu $75 \%$ tuntas secara keseluruhan. Maka kemampuan anak dalam membaca huruf hija'iah secara urut dan sesuai tanda baca fathah dan kasrah harus lebih ditingkatkan lagi untuk mencapai ketuntasan belajar. Kemampuan anak dalam membaca huruf hija'iah yang memperoleh kriteria cukup harus ditingkatkan dan anak yang memperoleh kriteria tidak baik harus lebih ditingkatkan, untuk itu perlu diadakan siklus II.

\section{Pada pelaksanaan tindakan} siklus II merupakan hasil perbaikan terhadap kelemahan dan kekurangan yang terjadi pada pelaksanaan pembelajaran disiklus I. Berdasarkan data hasil observasi anak pada siklus II ini, semua aspek kemampuan membaca huruf hija'iah anak yang diamati sudah termasuk baik, bahkan ada yang sangat baik Dengan demikian pada siklus kedua dalam penelitian ini, peneliti dapat menyimpulkan bahwa tujuan dari penelitian ini sudah tercapai dan kemampuan membaca huruf hij'iah anak sudah meningkat, sehingga penelitian ini peneliti cukupkan sampai siklus kedua.

\section{Kesimpulan dan Saran}

Berdasarkan hasil penelitian dan pembahasan dapat disimpulkan bahwa: Penerapan media pohon huruf hija'iah dapat meningkatkan kemampuan membaca huruf hija'iah pada anak Taman Kanak-kanak Tunas Harapan Kota Bengkulu terlihat dari hasil analisi $t_{\text {test }}$ diketahui bahwa $t_{\text {hitung }}$ sebesar 8,9 sementara $t_{\text {tabel }}$ 3,355 pada taraf signifikan $1 \%$, dengan demikian $t_{\text {hitung lebih besar dari } t_{\text {tabel }}}$ sehingga perhitungan uji $t_{\text {test }}$ pada penilaian ini dikatakan signifikan.

\section{Daftar Pustaka}

Ahmadi, Abu. 1990. Psikologi
Belajar. Jakarta: Rineka Cipta.

Alek. 2012. Metode Iqra'. http://inspirasia lex.wordpress.com/tag/metodeigro/H tm (Jam 10:15 Rabu, 25 April 2012) 
Anwar, Efendi. Bimbingan Tahsin dan Tajwid Al-Quran. Cahaya Quran.

Aqib, dkk. 2009. Penelitian Tindakan Kelas untuk Guru SD, SLB Dan TK. Bandung: CV. Yrama Widya.

Arikonto, Suharsimi, dkk. 2011. Penelitian Tindakan Kelas. Jakarta: Bumi Aksara.

Asnawir, Basyiruddin. Usman. 2002. Media Pembelajaran. Jakarta: Ciputat.

Azwar, Bony. 2010. Tsaabita Cara Cepat Dan Mudah Belajar Membaca Al-Quran. Jawa Tengah: Tsaabita "Rumah Quran".

Departemen Agama RI. 2005. AlQuran Dan Terjemahan. Bandung: Jart

Dhine, Nurbiana, dkk. 2007. Metode Pengembangan Bahasa. Jakarta: Universitas Terbuka.

Endang. 2007. Efektivitas Penggunaan Metode Aba Ta Tsa Dan Metode Iqra. Jakarta: Dalam Pembelajaran Al-Qur'an Di Ltqa AlHikmah Dan Ltqa At-Taqwa.

Fahmi, Habib, dkk. 1993. Pendidikan Agama Islam. Semarang: Cempakah Putih.

Hamalik. 2005. Keterampilan Dasar Mengajar. Malang: Fakultas Tarbiyah.

Hariyadi, Moh. 2009. Statistik Pendidikan Panduan Lengkap Dari Design Sampai Analisis
Statistik Pendidikan. Jakarta: PT. Prestasi Pustakaraya

Harjanto. 2010 .Perencanaan Pengajaran. Jakarta: Rineka Cipta

Hidayatullah, Furqon. 2010. Pendidikan Karakter Membangun Peradaban Bangsa. Surakarta: Yuma Pustaka

Kementrian Pendidikan Nasional, Direktorat Jendral Manajemen Pendidikan Dasar Dan Menengah, Direktorat Pembinaan Taman Kanakkanak Dan Sekolah Dasar Tahun 2010. Peraturan Mentri Pendidikian Nasional Repoblik Indonesia Nomor 58 Tahun 2009 Tentang Standar Pendidikan Anak Usia Dini (PAUD).

Kunandar. 2010. Langkah Mudah Penelitian Tindakan Kelas Sebagai Pengembangan Profesi Guru. Jakarta: PT Rajawali Pers.

Mukmin, Ch. 2010. Yang Tersirat Pada Huruf Hija'iyah. http://wadahsufi yah.blogspot.com/2011/06/yangtersirat-pada-huruf-hijaiyah.html (Jam 10:36 Rabu, 25 April 2012)

Muzzamil, Ahmad. 2009. Panduan Tahsin Tilawah. Jakarta.

Nugraha, Ali \& Rachmawati, Yeni. 2005. Metode Pengembangan Sosial Emosional: Universitas Terbuka.

Nurdin, Ali. 2010. Makhraj Huruf. http://

asalnudi.wordpress.coom/2010/06/30 1 mahraj-huruf-dalam-al-quran/ (j am09:45Rabu,25_November 2012 
Opini. 2012. Iqra'= Bacalah! Emangnya Apa Yang Mau Dibaca?.http://muda.ko mpasiana.com/2012/04/26/iqrabacala h-emang-apa yang-mau dibaca/ (Jam 10:45 Rabu, 25 April 2012 )

Opini. 2012. Prinsip-Prinsip Pembelajaran.

http://id.wikipedia.org/wiki/pembela jaran. (Jam 17.37 Kamis 13 Desember 2012)

Sugianto, Edi. 2011. Membuka Rahasia Huruf Hijaiyah. http://www. ulilalbab. Com/2011/05/membukarahasia-huruf-hijaiyah.html (Jam 22:20 Rabu, 07 November 2012.)

Sugiyono. 2010. Metode Penelitian Admidistrasi. Bandung: Alfabeta.

Susilowati, Septi. 2009. Upaya Meni ngkatkan Kemampuan Membaca Huruf Hijaiyah dengan Metode Drill RA An-Nahl Kalikabong Kalimanah Purbaling ga.library. walisongo.ac.id/digilib/gdl.php? mod =browse \&op (Jam 10:1 7 Rabu, 06 Desember 2012)

Wahyu, W. Yuniasri. 2011. Pemanfaatan Media Flashcard Hija'iah Dengan Pendekatan Beyond Center And Circle Time (BCCT) Untuk Meningkatkan Kemampuan Menghafal Huruf Hija'iah Pada Kelompok Bermain (Play Group) Di Paud Aisyiyah Trenggalek.

Yusuf, H. Abu. 2008. Adab Membaca Al-Quran. http://muslim.or.id/alquran /adab membaca-al-quran.html (Jam 21:16 Rabu, 07 November 2012). 